\title{
Perbedaan Peningkatan Prestasi Belajar IPA Melalui Pembelajaran Berbasis Masalah dan Inkuiri Terbimbing Pokok Bahasan Energi dan Daya Listrik Kelas IX di SMPN 20 Bandar Lampung
}

\author{
Tsamaniariaty Hidayah¹, Sulton Djasmi², Undang Rosidin ${ }^{3}$ \\ 1, 2,3 Universitas Negeri Lampung
}

\begin{tabular}{l} 
ARTICLE INFO \\
\hline Article History: \\
Received 05.01 .2018 \\
Received in revised \\
form 16.02.2018 \\
Accepted 26.03.2018 \\
Available online \\
16.04.2018
\end{tabular}

DOI: $10.30653 / 003.201841 .42$

\begin{abstract}
Difference Improving Learning Achievement of Science Through Learning Based On Problem And Discussion Guided Inquiry Energy And Power Supply Of Ninth Grade At Smpn 20 Bandar Lampung. The research aims to know: (1) difference in improving pretest and post-test of cognitive in learning based of problem. (2) difference in improving pre-test and post-test of cognitive in learning guided inquiry. (3) difference in improving student's post-test of cognitive in learning based of problem and guided inquiry. This research is an experimental research by "pre-tes post-test one group design". Population in this research is all of the students of ninth grade at SMPN 20 Bandar Lampung. Sampling by purposive technique of ninth grade A and ninth grade C. Data is analyzed by mean difference test. Conclusion in this research are: (1) there is a difference in improving between cognitive test score is learning based on problem 18,98 . (2) there is a difference in improving cognitive test score in learning guided inquiry 10,85 . (3) there is a difference in improving cognitive test score is learning based on problem with cognitive test score in guided learning 3,60.
\end{abstract}

Keywords:

Guided Inquiry, Learning Achievement of IPA Physics, PBL.

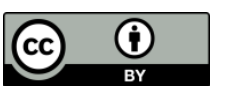

This is an open access article distributed under the terms of the Creative Commons Attribution 4.0 International License, which permits unrestricted use, distribution, and reproduction in any medium, provided the original work is properly cited. @ 2018 Tsamaniariaty Hidayah, Sulton Djasmi, Undang Rosidin.

\section{PENDAHULUAN}

Salah satu upaya untuk meningkatkan mutu pendidikan disekolah adalah dengan cara melalui perbaikan proses pembelajaran. Guru sebagai personil yang menduduki posisi strategis dalam rangka pengembangan sumber daya manusia, dituntut untuk terus mengikuti perkembangan konsep-konsep baru didalam dunia pembelajaran. Salah satu faktor yang mempengaruhi rendahnya prestasi belajar siswa adalah faktor sekolah yaitu proses pembelajaran yang merupakan inti dari proses pendidikan formal di sekolah yang di dalamnya terdapat interaksi antara guru, materi, dan siswa. Agar penciptaan lingkungan mencapai hasil yang optimal, guru harus memahami berbagai konsep dan teori yang berkaitan dengan proses belajar mengajar yang nantinya akan dipraktikkan dalam kegiatan mengajar.

\footnotetext{
${ }^{1}$ Corresponding author's address: Prodi AMIK Universitas Negeri Lampung, Indonesia
} e-mail: tsa.pasca12@yahoo.co.id 
Penyelenggaraan mata pelajaran Ilmu Pengetahuan Alam (IPA) terutama materi fisika di tingkat Sekolah Menengah Pertama (SMP) dimaksudkan sebagai wahana atau sarana untuk melatih siswa agar dapat menguasai pengetahuan, konsep dan prinsip fisika, memiliki kecakapan ilmiah, memiliki keterampilan proses sains serta dapat mengembangkan keterampilan berpikir kritis dan kreatif.

Kecenderungan pembelajaran IPA fisika hanya mempelajari fisika secara produk, menghafal konsep serta teori-teori dan hukum. Guru menggunakan beberapa model pembelajaran tetapi dengan tidak maksimal. Cara pembelajaran seperti ini menjadikan siswa pada umumnya hanya mengenal banyak peristiwa fisika secara hafal tanpa mereka memahami apa yang mereka hafalkan tersebut. Cara belajar seperti ini yang menyebabkan munculnya kejenuhan siswa pada pelajaran fisika.

Berdasarkan hasil nilai ulangan harian mata pelajaran IPA ganjil siswa kelas IX SMP Negeri 20 Bandar Lampung tahun 2012/2013, diketahui bahwa prestasi belajar siswa belum mencapai nilai maksimal dikarenakan KKM yang berlaku di sekolah sebesar 72 belum tercapai seluruhnya. Ada beberapa Kopetensi Dasar yang belum tuntas terlihat dari analisis soal ulangan harian siswa. Rendahnya hasil belajar IPA siswa kelas IX SMP Negeri 20 Bandar Lampung karena penerapan kegiatan pembelajaran IPA di SMP Negeri 20 Bandar Lampung belum menerapkan pembelajaran yang mengaktifkan siswa dalam pembelajaran di kelas.

Sedangkan hasil wawancara yang dilakukan peneliti kepada siswa diketahui bahwa pembelajaran fisika kurang mereka sukai karena mereka kurang memahami apa yang sebenarnya mereka pelajari. Guru kurang memberikan contoh-contoh dalam kehidupan sehari-hari yang dapat mereka pahami. Selama ini guru tidak mengajak siswa aktif dalam pembelajara, siswa hanya mendengarkan apa yang guru sampaikan saja setelah itu guru memberikan latihan dan tugas sehingga siswa merasa bosan dengan metode belajar yang selama ini dilakukan oleh guru.

Berbagai kesulitan dalam mempelajari IPA fisika tersebut membuat siswa tidak tertarik dan cenderung menjauhi IPA fisika. Seharusnya guru IPA membuka paradigma baru dalam menentukan model pembelajaran IPA fisika di kelas yang dapat membuat siswa tertarik. Sudah saatnya merubah IPA yang selama ini dianggap sebagai mata pelajaran yang membosankan dan menakutkan berubah menjadi sesuatu yang menyenangkan dan mengasikkan.

Ada beberapa hal yang dapat dilakukan oleh guru dalam memperbaiki keadaan siswa untuk mencapai tujuan pembelajaran dimulai dari memperbaiki metode, pendekatan bahkan model yang dapat membangkitkan siswanya untuk memotivasi belajar. Guru juga harus dapat menghadirkan pembelajaran yang menarik dan diminati oleh siswa. pembelajaran yang dapat digunakan untuk mengaktifkan siswa adalah pembelajaran berbasis masalah atau problem based learning dan inkuiri terbimbing yang disertai suatu metode yang diharapkan dapat mampu meningkatkan hasil belajar siswa.

Bruner (1963) menganggap bahwa teori belajar penemuan sesuai dengan pencarian pengetahuan secara aktif oleh manusia dan dengan sendirinya memberikan hasil yang paling baik, berusaha sendiri untuk mencari pemecahan masalah sendiri serta pengetahuan yang menyertainya serta menghasilkan pengetahuan yang benar-benar bermakna. Selanjutnya Bruner menyatakan bahwa pengetahuan yang diperoleh dengan belajar melalui penemuan menunjukan kebaikan antara lain: pengetahuan yang didapatkan akan bertahan lebih lama dibandingkan dengan pengetahuan yang dipelajari dengan cara lain, hasil belajar penemuan mempunyai efek transper yang lebih baik dari pada hasil belajar lainnya.

Pandangan konstruktivis-kognitif mengemukakan, siswa dalam segala usia secara aktif terlibat dalam proses perolehan informasi dan membangun pengetahuan mereka sendiri. Pengetahuan mereka tidak statis, tetapi terus menerus tumbuh dan berubah saat siswa menghadapi pengalaman baru yang memaksa mereka membangun dan memodifikasi pengetahuan awal.

Arends \& Kilcher (2010) menyeleksi enam model pengajaran yang sering dan praktis digunakan guru dalam mengajar, yaitu: presentasi, pengajaran langsung, pengajaran konsep, pembelajaran kooperatif, pengajaran berdasarkan masalah dan diskusi kelas. 
Model pembelajaran yang digunakan dalam penelitian ini adalam model pembelajaran barbasis masalah dan model pembelajaran berbasisi inkuiri terbimbing. Diharapkan melalui dua model pembelajaran tersebut prestasi belajar siswa akan meningkat. Pembelajaran berbasis masalah merupakan suatu bentuk pembelajaran yang materi kegiatannya erat hubungannya dengan pengalaman nyata siswa. Dalam pembelajaran berbasis masalah guru menciptakan situasi dan isi pembelajaran secara khusus yaitu memberi kesempatan siswa untuk dapat melakukan pemecahan suatu masalah, latihan-latihan serta tugas secara nyata dan otentik.

Pembelajaran berbasis masalah tidak dirancang untuk membantu guru memberikan informasi sebanyak-banyaknya kepada siswa, tetapi pembelajaran berbasis masalah dikembangkan untuk membantu siswa mengembangkan kemampuan berpikir, memecahkan masalah serta keterampilan intelek seperti: belajar berbagai peran orang dewasa melalui pelibatan mereka dalam pengalam nyata atau simulasi dan menjadi pembelajar yang otonom dan mandiri (Ibrahim \& Nur, 2012).

Sintaks suatu pembelajaran berisi langkah-langkah praktis yang harus dilakukan oleh guru dan siswa dalam suatu kegiatan. Menurut Ibrahim (dalam Trianto, 2011: 97) di dalam kelas pembelajaran berbasis masalah peran guru berbeda dengan kelas tradisional, peran guru dalam pembelajaran berbasis masalah adalah:

1) Mengajukan masalah atau mengorentasikan siswa kepada masalah autentik, yaitu masalah kehidupan nyata sehari-hari.

2) Memfasilitasi/membimbing penyelidikan misalnya melakukan pengamatan atau melakukan eksperimen/percobaan.

3) Memfasilitasi dialog siswa.

4) Mendukung belajar siswa.

Pembelajaran inkuiri merupakan model pembelajaran dimana dalam pembelajaran inkuiri ini siswa dengan proses mentalnya sendiri dapat menemukan suatu konsep atau prinsip. Sehingga dalam penyusunan rancangan percobaan dilakukan atas kemampuannya sendiri. Menurut Sanjaya (2008: 196) inkuiri adalah rangkaian kegiatan pembelajaran yang menekankan pada proses berpikir secara kritis untuk mencari dan menemukan sendiri jawaban dari suatu masalah yang dipertanyakan. Proses berpikir itu sendiri biasanya dilakukan melalui tanya jawab antara guru dan siswa.

Dalam penelitian ini tahapan pembelajaran inkuiri terbimbing mengikuti tahapan dari Eggen \& Kauchak (2006), yaitu sebagai berikut ini: 1) Menyajikan pertanyaan atau masalah; 2) Membuat hipotesis; 3) Merancang percobaan; 4) Melakukan percobaan untuk memperoleh informasi; 5) Mengumpulkan dan menganalisis data; dan 6) Membuat kesimpulan.

\section{METODE}

Penelitian ini merupakan penelitian eksperimen dengan terlebih dahulu mengembangan model pembelajaran berbasis masalah dan inkuiri terbimbing. Setelah mengembangkan model pembelajaran peneliti melakukan penelitian eksperimen, dengan menggunakan metode quasi eksperimen dengan "pretest-postest one group design" pada kelompok-kelompok ekuivalen.

Populasi dalam penelitian ini adalah seluruh siswa kelas IX SMP Negeri 20 Bandar Lampung tahun pelajaran 2013-2014 sebanyak 204 orang siswa. Sampel penelitian adalah sebagian anggota populasi target yang diambil dengan menggunakan teknik purposive dengan cara claster yaitu kelas IX A, dan IX C, yang masing-masing berjumlah 36 orang. Kedua kelas ini dinilai setara, terlihat pada ratarata nilai semester ganjil kelas IX A 66 dan IX C 66. Kelas IX A akan belajar dengan pembelajaran inkuiri terbimbing dan kelas IX C akan belajar dengan pembelajar berbasis masalah.

Desain awal penelitian ini adalah melakukan pengembangan kedua model pembelajaran ini dengan menggunakan desain pengembangan ASSURE melalui tahap-tahap: 1) Analyze Learner (menganalisis pembelajar); 2) State Standards and Objectives (menentukan standard dan tujuan); 3) Select Strategies, Technology, Media, and Materials (memilih, strategi, teknologi, media dan bahan ajar); 4) Utilize Technology, Media and Materials (menggunakan teknologi, media dan bahan ajar); 5) Require Learner Parcipation (mengembangkan partisipasi peserta didik); dan 6) Evaluate and Revise (mengevaluasi dan merevisi). 


\section{HASIL DAN PEMBAHASAN}

Pada hipotesis satu, peneliti membuktikan apakah terdapat perbedaan peningkatan nilai tes akhir dan nilai tes awal ranang kognitif pada pembelajaran berbasis masalah dan peneliti telah membuktikan bahwa ada perbedaan peningkatan nilai tes akhir dan nilai tes awal ranah kognitif pada pembelajaran berbasis masalah yang ditunjukkan dengan hasil uji statistik yaitu nilai thitung perbedaan pembelajaran sebesar 18,985 yang berarti lebih besar dari 0.05 dan nilai Sig. (2-tailed) = $0,00<0,025$ sehingga dapat disimpulkan terima $\mathrm{H}_{1}$ dan tolak $\mathrm{H}_{0}$, ada perbedaan peningkatan, antaran nilai tes akhir dan nilai tes awal ranah kognitif pada pembelajaran berbasis masalah.

Hipotesis ke dua peneliti membuktikan apakah terdapat perbedaan peningkatan nilai tes akhir dan nilai tes awal ranah kognitif pada pembelajaran inkuiri terbimbing. Dari hasil penelitian telah dibuktikan bahwa ada perbedaan nilai tes akhir dan nilai tes awal ranah kognitif pada pembelajaran inkuiri terbimbing yang ditunjukkan dengan hasil uji statistik yaitu nilai thitung interaksi pembelajaran sebesar 10,855 yang berarti lebih besar dari 0.05 dan nilai Sig. (2-tailed) $=0,00<0,025$ sehingga terima $\mathrm{H}_{1}$ dan tolak $\mathrm{H}_{0}$ ada perbedaan peningkatan antaran nilai tes akhir dan nilai tes awal ranah kognitif pada pembelajaran inkuiri terbimbing.

Hipotesis ke tiga peneliti membuktikan apakah terdapat perbedaan nilai tes akhir siswa ranah kognitif pada pembelajaran berbasis masalah dan nilai tes akhir siswa ranah kognitif pada pembelajaran inkuiri terbimbing. Dari hasil penelitian telah dibuktikan bahwa ada interaksi nilai tes akhir siswa ranah kognitif pada pembelajaran berbasis masalah dan nilai tes akhir siswa ranah kognitif pada pembelajaran inkuiri terbimbing yang ditunjukkan dengan hasil uji statistik yaitu nilai thitung interaksi pembelajaran sebesar 3,604 yang berarti lebih besar dari 0.05 dan nilai Sig. (2tailed $)=0,01<0,025$ sehingga terima $\mathrm{H}_{1}$ dan tolak $\mathrm{H}_{0}$ ada perbedaan antaran nilai tes akhir siswa ranah kognitip pada pembelajaran berbasis masalah dan nilai tes akhir siswa ranah kognitif pada pembelajaran inkuiri terbimbing.

\section{Peningkatan Nilai Tes Akhir dan Nilai Tes Awal Ranah Kognitif pada Pembelajaran Berbasis Masalah}

Setelah diberi pembelajaran berbasis masalah, kemampuan akhir siswa meningkat yang mengakibatkan meningkat pula prestasi belajar siswa pada akhir pembelajaran. Hal ini terjadi karena pada pembelajaran berbasis masalah sangat memberikan tekanan pada penyelesaian suatu masalah secara menalar, siswa sendiri yang menemukan jawaban berdasarkan pengetahuan yang siswa ketahui, pemahaman yang siswa miliki dari pelajaran yang lain atau pembelajaran sebelumnya serta keterampilan yang mereka miliki sehingga pemahaman siswa melekat lebih lama di dalam ingatan siswa. Selain itu siswa merasa senang dan tertarik, hai itu dapat terlihap pada antusias siswa dalam menerima langkah -langkap pembelajaran berbasis masalah. Melalui langkahlangkah pembelajaran berbasis masalah siswa diajak untuk membangun sendiri pengetahuanya. Berdasarkan penelitian pada tahap kedua siswa sudah mulai aktif dalam proses pembelajaran.

Menurut pendapat Skinner (1989) dalam membangun pengetahuan melalui proses belajar, siswa meliputi tiga fase yaitu fase eksplorasi, pengenalan konsep dan aplikasi. Hal ini sesuai dengan langkah dalam pembelajaran berbasis masalah. Pada fase ekslorasi siswa digiring untuk mempelajari gejala-gejala yang terjadi di sekeliling siswa melalui bimbingan dari guru. Siswa diajak untuk menganalisis permasalahan dan membuat jawaban sementara tentang itu semua dan pada akhirnya akan mereka buktikan melalui peratikum. Pada fase pengenalan konsep siswa diajak oleh guru untuk mengenal konsep tersebut melalui hal-hal yang ada hubungannya dengan gejala yang sedang dipelajari oleh siswa. Guru membimbing siswa untuk melakukan pratikum dan menemukan jawaban dari konsep yang mereka teliti. Dan pada fase terakhir siswa dapat mengaplikasikan konsep tersebut pada masalah yang lain tetapi tetap berkaitan dengan konsep awal.

Semua hal diatas guru desain agar tetuang di dalam langkah-langkah pembelajaran berbasis masalah yang telah didesain, guru tidak berperan sebagai fasilisator tetapi berperan sebagai pembimbing, mengadakan dialog, membantu dan memberikan fasilitas dalam penyelidikan. Selain 
itu, guru juga memberikan dorongan dan dukungan yang dapat meningkatkan pertumbuhan intelektual siswa. Pada pembelajaran berbasis masalah, di dalam melakukan eksperimen siswa tidak dibimbing oleh guru melainkan siswa sendiri yang menemukan jawaban berdasarkan pengetahuan, pemahaman dan keterampilan yang siswa miliki sebelumnya, guru hanya membimbing siswa untuk memecahkan masalah tersebut. Hal itulah yang menimbulkan rasa penasaran sehingga siswa mencari jawabannya sendiri dan proses mencari jawaban dalam pratikum tersebut akan melekat kuat diingatan siswa.

\section{Peningkatan Nilai Tes Akhir dan Nilai Tes Awal Ranah Kognitif pada Pembelajaran Inkuiri Terbimbing}

Pada proses pembelajaran inkuiri terbimbing memberikan cara bagi siswa untuk membangun kecakapan-kecakapan intelektual (kecakapan berpikir) terkait dengan proses-proses berpikir reflektif. Hal tersebut tertuang didalam langkah-langkah kegiatan pada pembelajaran inkuiri terbimbing. Kegiatan yang guru berikan kepada siswa meliputi aktivitas belajar yang dapat semakin bermakna dan dapat diperluas ketika siswa berhadapan dengan situasi dimana konsep diterapkan. Didalam situasi ini siswa mengintegerasikan pengetahuan dan keterampilan secara terus-menerus dan mengaplikasikannya dalam konteks yang relefan dengan kehidupan nyata yang siswa hadapi.

Hal ini sesuai dengan pendapat Kuhne (1993) yang menyebut bahwa pembelajaran berdasarkan inkuiri terhadap siswa dapat membantu mereka menjadi lebih kreatif, mereka lebih berpikir positif dan mereka lebih percaya diri sesuai dengan tujuan dari penggunaan strategi pembelajaran inkuiri adalah mengembangkan kemampuan intelektual sebagai bagian dari proses mental, akibatnya dalam pembelajaran inkuiri siswa tidak hanya dituntut agar menguasai pelajaran saja, akan tetapi bagaimana mereka dapat menggunakan potensi yang dimilikinya. Hal tersebut berlaku bagi semua siswa termasuk siswa yang membutuhkan perhatian khusus selama proses pembelajaran sehingga dengan menggunakan pembelajaran inkuiri terbimbing dapat meningkatkan prestasi belajar siswa menjadi lebih baik.

Pembelajaran inkuiri terbimbing didesain oleh peneliti sehingga dapat memenuhi kebutuhan pembelajaran IPA yang membutuhkan ketelitian, pembuktian dan juga penelitian. Pada penelitian ini peneliti merancang pembelajaran inkuiri sehingga dapat memenuhi kebutuhan setiap siswa, baik bagi siswa yang aktif atau siswa yg pasif.

\section{Peningkatan Nilai Tes Akhir Pembelajaran Berbasis Masalah dan Nilai Tes Pembelajaran Inkuiri Terbimbing}

Sesuai dengan pendapat Brunner bahwa belajar adalah suatu proses aktif dimana peserta didik membangun atau mengkonstruk pengetahuan baru berdasarkan pada pengalaman atau pengetahuan yang sudah dimilikinya. Apabila dilihat menggunakan pandangan konstruktivisme bahwa belajar bukan semata-mata mentransper pengetahuan yang ada diluar dirinya tetapi belajar lebih pada bagaimana otak memproses dan menginterpretasikan pengalaman yang baru dengan pengetahuan yang terlebih dahulu telah dimilikinya dalam bentuk yang baru. Karena hal tersebu maka pada siswa yang menggunakan pembelajaran berbasis masalah pemahaman yang mereka miliki melekat lebih lama sehingga prestasi belajar mereka pada akhir pembelajaran tetap kuat. Selain itu pembelajaran berbasis masalah merupakan interaksi antara stimulus dan respon yang merupakan hubungan dua arah atau timbal balik antara belajar dan lingkungan belajar.

Seperti diketahui bahwa pelajaran IPA berkaitan dengan cara mencari tahu tentang alam secara sistematis, sehingga IPA bukan hanya kumpulan pengetahuan yang berupa fakta-fakta, konsepkonsep, atau prinsip-prinsip saja tetapi juga merupakan proses penemuan. Selain itu kegiatan pembelajaran IPA mencakup pengembangan kemampuan dalam mengajukan pertanyaan, mencari jawaban, memahami jawaban, menyempurnakan jawaban tentang "apa", "mengapa", dan "bagaimana" tentang gejala alam maupun karakteristik alam sekitar melalui cara-cara sistematis yang akan diterapkan dalam lingkungan dan teknologi. Kegiatan tersebut dikenal dengan kegiatan ilmiah yang didasarkan pada metode ilmiah. Kegiatan-kegiatan dalam proses pelajaran IPA 
tersebut sesuai dengan pembelajaran berbasis masalah, sehingga siswa dapat dengan mudah memahami materi yang sedang mereka pelajari.

Seperti kita ketahui bahwa belajar merupakan suatu proses aktif di mana peserta didik membangun (mengkonstruk) pengetahuan baru berdasarkan pada pengalaman atau pengetahuan yang telah dimilikinya. Dalam pandangan konstruktivisme, belajar bukanlah semata-mata mentransfer pengetahuan yang ada di luar dirinya, tetapi belajar lebih pada bagaimana otak memproses dan menginterpretasikan pengalaman yang baru dengan pengetahuan yang sudah dimilikinya dalam format yang baru. Proses pembangunan ini bisa melalui asimilasi atau akomodasi.

\section{SIMPULAN}

Ada perbedaan peningkatan nilai tes akhir dan nilai tes awal ranah kognitif pembelajaran berbasis masalah mata pelajaran IPA fisika di SMPN 20 Bandar Lampung. Peningkatan tersebut terjadi dikarenakan semua proses pembelajaran berbasis masalah dapat memenuhi kebutuhan belajar siswa dan sesuai dengan karakteristik mata pelajaran IPA fisika yang membutuhkan eksperimen dengan menggunakan metode ilmiah dan dapat meningkatkan motivasi belajar siswa .

Terdapat perbedaan peningkatan nilai tes akhir dan nilai tes awal ranah kognitif pada pembelajaran inkuiri terbimbing mata pelajaran IPA fisika di SMPN 20 Bandar Lampung. Sehingga berdasarkan hasil penelitian didapatkan bahwa pada pembelajaran inkuiri terbimbing dapat memenuhi kebutuhan belajar siswa baik kebutuhan dalam hal pemecahan suatu masalah dalam pelajaran IPA ataupun kebutuhan dalam karakteristik siswa SMP yang memiliki rasa ingin tahu yang tinggi.

Terdapat perbedaan peningkatan nilai tes akhir siswa ranah kognitif pembelajaran berbasis masalah dan nilai tes akhir siswa ranah kognitif pembelajaran inkuiri terbimbing. Hasil yang didapatkan adalah nilai tes akhir pada pembelajaran berbasis masalah lebih besar dibandingkan dengan nilai tes akhir pembelajaran inkuiri terbimbing. Hal ini dikarenakan pada pembelajaran berbasis masalah semua kegiatan pembelajaran difokuskan kepada siswa, guru hanya menjadi pendamping sehingga pengalaman yang siswa dapatkan benar-benar didapatkan dari hasil kerja siswa sendiri sehingga pemahaman yang siswa peroleh melekat lama diingatan siswa. Sedangkan pada pembelajaran inkuiri terbimbing siswa merasa tergantung pada bimbingan dari guru dalam menyelesaikan semua permasalahan yang guru berikan.

\section{REFERENSI}

Arends, D., \& Kilcher, A. (2010). Teaching for student learning: Becoming an accomplished teacher. Routledge.

Bruner, J. S. (1963). Needed: A theory of instruction. Educational Leadership, 20(8), 523-532.

Dimyati, \& Mudjiono. (2006). Belajar dan Pembelajaran cetakan ke-3. Jakarta: Rineka Cipta.

Eggen, P. D., \& Kauchak, D. P. (2006). Strategies and models for teachers: teaching content and thinking skills, (5th ed.). Boston: Pearson/Allyn and Bacon

Ibrahim, M., \& Nur, M. (2012). Pembelajaran Berbasis Masalah. Surabaya: Unesa Press.

Kuhne, B. M. R. (1993). The Library: The Brain of the School? The School Library As a Resource in "Free Inquiry Learning". Unpublished doctoral dissertation, Lunds University (Sweden).

Sanjaya, W. (2008). Perencanaan dan Desain Sistem Pembelajaran. Jakarta: Kencana Prenada Media Grup.

Skinner, B. F. (1989). The origins of cognitive thought. American Psychologist, 44(1), 13-18.

Smaldino, S. E., Lowther, D. L., Russell, J. D., \& Mims, C. (2011). Instructional Technology and Media For Learning. Jakarta: Kencana Prenada Media Grup.

Tan, O. S. (2004). Echancing Thinking through Problem-based Learning Approaches. Singapura: Thomson Learning Devision.

Trianto. (2011). Mendesain Model Pembelajaran Inovatif-Progresif. Jakarta: Kencana Prenada Media Group. 